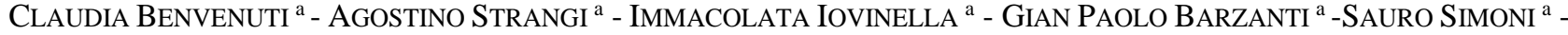 SALVATORE VITALE ${ }^{\mathrm{b}}$ - LAURA LUONGO ${ }^{\mathrm{b}}$ - VALERIA FRANCARDI $^{\mathrm{a}}$. PIO FEDERICO ROVERSI ${ }^{\text {a }}$
}

\section{XYLOSANDRUS COMPACTUS AND LIPARTHRUM COLCHICUM (COLEOP- TERA SCOLYTINAE) IN TUSCANY: A PRELIMINARY SCREENING OF ASSOCIATED FUNGI}

\author{
${ }^{a}$ Council for Agricultural Research and Economics - Research Centre for Plant Protection and Certification \\ (CREA-DC), Via Lanciola 12/A, 50125, Cascine del Riccio, Impruneta (Firenze), Italy \\ ${ }^{b}$ Council for Agricultural Research and Economics - Research Centre for Plant Protection and Certification \\ (CREA-DC), Via C.G. Bertero 22, 00156 - Roma, Italy \\ Corresponding Author: Claudia Benvenuti, claudia.benvenuti@crea.gov.it
}

\begin{abstract}
Benvenuti C., Strangi A., Iovinella I., Barzanti G. P., Simoni S., Vitale S., Luongo L., Francardi V., Roversi P.F. Xylosandrus compactus and Liparthrum colchicum (Coleoptera Scolytinae) in Tuscany: a preliminary screening of associated fungi.

Xylosandrus compactus and Liparthrum colchicum are two Scolytinae recorded for the first time in Italy in 2011 and 2019, respectively. X. compactus is an "ambrosia beetle" causing damages to several plants typical of the Mediterranean maquis through its digging activity on twigs and branches of the host plants. L. colchicum is a "bark beetle", monophagous on laurel shrubs and trees. During a survey performed in summer of 2020, in "Tenuta Salviati" located in the Migliarino Natural Park (Pisa, Tuscany), adults of X. compactus and L. colchicum were collected from the same branches and apical twigs of Laurus nobilis hedges. The study aimed at characterizing fungi isolated from the external surface of the two scolytids bodies, to evaluate similarities and even their role in fungal spreading in the environment.
\end{abstract}

KeY WORDS: ambrosia beetle; bark beetle; Cladosporium spp.; Geosmithia spp.; Laurus nobilis; phytopathogenic fungi.

\section{INTRODUCTION}

Xylosandrus compactus (Eichhoff) (black twig borer) is a scolytid beetle native to South Eastern Asia and accidentally introduced to several areas of Africa, North and South America and Europe (WoOD, 1982; WoOD and BRIGHT, 1992; WOOD, 2007). The adult females attack twigs and branches of the host plants digging breeding galleries where they lay eggs and spread ambrosia fungi (e.g. Ambrosiella xylebori, A. macrospora), which serve as food for adults and larvae. In the last decade, severe damages were reported in the EPPO region to cause the gradual decline and ultimate dieback of the attacked plants. More than 220 plant species, belonging to 62 different families, have been reported as suitable hosts for this pest in native or introduced areas; some of them (such as Coffea arabica L., Camellia sinensis L., Mangifera indica L., Persea americana Mill. and Theobroma cacao L.) have considerable commercial value (NGOAN et al., 1976; WOOD, 1982; DIXON and WOODRUFF, 1983; MESHRAM et al., 1993; INTACHAT and KIRTON, 1997; DAEHLER and DUDLEY, 2002; MATSUMOTO, 2002). For this reason, since 2017, $X$. compactus has been included in the EPPO alert list (EPPO RS 2017/032) of alien and invasive species.

In Italy this pest was observed for the first time in 2011 (FITOLAB, 2011a, b) on Laurus nobilis L., Quercus ilex L., Castanea sativa Mill., Fraxinus ornus L. and Celtis australis L. in urban parks located near Naples (GARONNA et al., 2012). Subsequently new discoveries occurred in different Italian regions: Liguria and Tuscany in 2012, Lombardy in 2015, Lazio and Sicily in 2016, Emilia Romagna in 2018 and Veneto 2019 (FRANCARDI et al., 2012; LONGO and TROPEA GARZIA, 2016; GugliuZzo et al., 2019a; GUGLIUZZO et al., 2019b; GUGLIUZZO et al., 2019c; FACCOLI, 2021). The rapid spread of this insect, due to its adaptation to the Mediterranean climate, caused significant damages to several plant species typical of the Mediterranean maquis. In Tuscany, extensive damages were observed in several environments, as well as on laurel hedges in monumental public and private urban parks.

Moreover, it should be noted that: X. compactus is associated with a number of fungi (along the main nutritional symbionts) located not only on the mycangium but also in other parts of the beetle body (as showed by BATEMAN et al., 2016); some of these fungi can be pathogenic such as Fusarium solani, Geosmithia pallida (Hypocreales: Bionectriaceae) and Epicoccum nigrum (Pleosporaceae: Hypocreaceae) (BATEMAN et al., 2016; VANNINI et al., 2017; MORALES-RODRÍGUEZ et al., 2020). The combined effect due to both activities of colonizing insects and pathogenic fungi might represent a further stress factor in attacked plants and, consequently, a major concern from a phytosanitary perspective.

The surveys carried out on plants attacked by $X$. compactus allowed also the detection of another Scolytinae: Liparthrum colchicum. This species was recently recorded, for the first time in Italy, on L. nobilis 
(FRANCARDI et al., 2021). This bark beetle lives exclusively on laurel trees and it is currently considered a species native to Mediterranean countries (JORDAL et al., 2004).

During the spring, L. colchicum generally attacks the distal part of laurel twigs; together with X. compactus, which is preferentially attracted to the basal parts of the same twigs, might contribute to the desiccation of the affected plants (FRANCARDI et al., 2012).

Adults dig circular entrance holes, ranging from 0.5 to $1.0 \mathrm{~mm}$ in diameter, into the subcortical region of twigs. The main characteristics of maternal chamber and inner galleries have been described by WoOD (2007) for the genus Liparthrum spp. The tunnelling activity of larvae, inside the colonized twigs, is externally detectable by observing typical light yellow/orange circular streaks/rings. This insect might also play a role as a vector of phytopathogenic fungal species as suggested by KOLAŘíK et al. (2007), that reported three species of the well-known phytopathogenic genus Geosmithia (Ascomycota, Hypocreales) associated with this bark beetle on laurel.

The aim of the present study was to characterize the fungal communities, including commensals, mutualistic and entomopathogenic fungi, carried by $X$. compactus and L. colchicum in "Tenuta Salviati" near Migliarino Natural Park - Pisa, a site where both species coexist and where the combined feeding activities resulted in a widespread damage on the same laurel hedges. The ecological and/or phytopathological significance of the distribution and association of the fungi with the insect species are discussed and evaluated to insight possible economic and ecological threats posed by the two insects.

\section{MATERIALS AND METHODS}

\section{SAMPLING}

Branches and apical twigs of Laurus nobilis with symptoms described by FRANCARDI et al. (2012); PENNACCHIO et al. (2012); FRANCARDI et al. (2017) were collected in laurel hedges in "Tenuta Salviati" near a natural park of Migliarino (Pisa) $\left(43^{\circ} 46^{\prime} 07.00^{\prime \prime} \mathrm{N}\right.$, $\left.10^{\circ} 19^{\prime} 27.33^{\prime \prime} \mathrm{E}\right)$. During summer of 2020, 100 short branches with leaves and twigs were sampled and each sample was approximately $20 \mathrm{~cm}$ in length with a diameter ranging from 0.5 to $1 \mathrm{~cm}$. Single branches were placed separately into plastic bags for transportation and stored in Firenze CREA-DC laboratory at $+4.0^{\circ} \mathrm{C}$ until analysis.

In the laboratory, all branches were cut lengthwise with a sterilised scalpel near the entrance holes of both adult insects and their galleries were carefully inspected under a stereo-microscope (Nikon SMZ 10A); all detected $X$. compactus and L. colchicum specimens were collected with a sterilized fine brush and maintained separately considering their respective galleries.

\section{INSECT AND FUNGI IDENTIFICATION}

a) Insect identification

The species identification of the insects was obtained through analysis of morphological characters and molecular procedures. Morphological identification was performed by adopting the keys of PFEFFER (1995), WOOD (2007) and FRANCARDI et al. (2017). Both for X. compactus and L. colchicum, molecular identification was carried out for one single specimen using the protocol described by KIRAN et al. (2019); species attribution was assessed through homology search in GenBank database.

b) Fungal isolation and classification

In order to investigate the fungal taxa associated with $X$. compactus and $L$. colchicum, 30 adults of both species, previously identified, were individually set onto a PDA substrate (Potato Dextrose Agar, VWR) in a $90 \mathrm{~mm}$ Petri plate (1 adult/plate) and allowed to freely walk for 30 minutes, as reported by other authors (VANNINI et al., 2017; GuGLIUZZO et al., 2020). After this lapse of time, insects were discarded from the plates. All the plates, sealed with laboratory film, were placed at $24^{\circ} \mathrm{C}$ in the dark. After $72 / 96$ hrs, plates were inspected for developing colonies by counting of Colony Forming Units (CFUs). From the resulting colonies, one transfer, representative of each colony type, was placed onto fresh PDA plates $(60 \mathrm{~mm})$ in order to obtain pure cultures growing at $24^{\circ} \mathrm{C}$ in the dark. Fungal colonies were sub cultured, examined for their microscopic characteristics and grouped according to their micro and morphological characters. The representatives of each morpho-type were selected and purified for molecular identification.

Aliquots of mycelium and conidia (about $10 \mathrm{mg}$ maximum) representing the selected morpho-type were frozen at $-80^{\circ} \mathrm{C}$ and, subsequently, homogenized with a mix of $500 \mu \mathrm{m}$ - and 2,0 mm-diameter glass beads (1:1 v/v) using a mechanical beater (Precellys 24, Precellys). Genomic DNA was extracted using Dneasy Plant Mini Kit (QIAGEN) according to the manufacturer's instructions; the final elution step was performed in 100 $\mu \mathrm{l} \mathrm{ddH}_{2} \mathrm{O}$. The rDNA ITS region was amplified by conventional PCR using the primers ITS5 and ITS4 (WHITE et al., 1990). Amplicons were sequenced in both directions at Bio-Fab Research Company (Rome, Italy) and assembled with Geneious 2021 software. Sequences were aligned with additional accessions obtained from GenBank using BLASTn program (http://blast.ncbi. nlm.nih.gov).

\section{STATISTICAL ANALYSIS}

Frequencies of association between $X$. compactus/ $L$. colchicum specimens and the identified fungal genera were assessed and analyzed by chi square test. Differences in fungal communities, within the two insect species, were assessed by different ecological parameters (Dominance, Shannon, Evenness, Simpson, Menhinick, Margalef, Equitability, Fisher and Berger-Parker indexes). Over all indexes, significance in diversity of fungi associated to the two insect species was evaluated by the Monte Carlo permutation test (BROWN and ROTHERY, 1993).

In order to evaluate the possibility of the two different insects to carry and spread the fungal community within the same habitat, a non-metric multidimensional scaling (NMDS) analysis was performed to represent, as closely as possible, the pairwise dissimilarity between the two insect species. Rarefaction curves were constructed to 
estimate and compare the richness of the two fungal communities at the abundance level of the smallest sample (CHAO et al., 2014).

The statistical analyses were computed using Past software (version 4.03) (HAMMER et al., 2001).

\section{RESULTS}

The morphological and molecular analysis of all the specimens collected in Migliarino Natural Park allowed the identification of the two species as Xylosandrus compactus and Liparthrum colchicum. The sequences of COX I mitochondrial gene obtained from the two individuals respectively showed an identity of $100 \%$ with Xylosandrus compactus (Accession number MW961427) and 100\% with L. colchicum (Accession number MT264965). Sequences of $X$. compactus and $L$. colchicum were submitted to GenBank with Accession numbers MW532748 and MT264966.

The screening focused on identification of the fungal isolates carried by the two scolytids resulted in 281 CFUs. More specifically, 204 CFUs from X. compactus were identified and grouped in 28 morpho-types, while 77 CFUs from L. colchicum were grouped in 14 morphotypes. Molecular analyses on morpho-types identified 11 and 9 different genera of fungi respectively. The most abundant fungal genera found on insect bodies were Cladosporium and Geosmithia (Fig. I). These genera represented the commonest fungi carried outside the body of $X$. compactus $(83 \%$ and $76 \%$ specimens respectively) while the same genera were found on about $30 \%$ and $33 \%$ L. colchicum specimens respectively.

The number of fungal colonies originated from the two insects showed a greater association between $X$. compactus and fungi - all $30 \mathrm{X}$. compactus specimens tested were associated to two fungal genera at least - than that evaluated for $L$. colchicum (chi square test, $\mathrm{P}=0.04$ ). By considering all the fungi registered, regardless of the genus, the number of CFUs originated by $X$. compactus was three times higher than that registered for $L$. colchicum.

However, considering the fungal communities associated with the two scolytids, we can observe nonsignificant differences between biodiversity indexes (Table 1). The only significant difference was found in the number of CFUs by Berger-Parker dominance index (Monte Carlo permutation test $\mathrm{P}=0.04$ ): the higher value registered for $X$. compactus may be ascribable to the most abundant genera represented in these samples. The substantial uniformity between fungal communities associated with the two scolityds could be found also in the species richness. Assuming that individuals in the same environment are randomly distributed and sample size is sufficiently congruous, the individual rarefaction curves show that in a hypothetical population size of 75 CFUs, L. colchicum should have only 8 different genera, while $X$. compactus 9 genera (Fig. II). Considering the total number of CFUs and their frequencies, the NMDS analysis of the fungal communities showed that the two insect species are clearly separated in carrying ability for a different quantity of fungal spores on the external surface of the body (Fig. III).

\section{DISCUSSION}

The association between bark and/or ambrosia beetles and fungi is well known and largely studied (e.g. BEAVER et al., 1989; JANKOWIAK et al., 2007; MORALESRODRÍGUEZ et al., 2020). The strength of association is deeply affected by the environment and species considered. Sampling places, isolation methods and species determination techniques are key factors to be considered when different associations between fungi and insects are compared. In this study, the fungal communities associated with the two scolytid species living on branches and apical twigs in a unique spot of laurel trees are compared.

As the unique environment and area of study, this could be explained with the different morphology of external structures where spores could interact.

Ambrosiella fungi have been reported to be associated with ambrosia beetles in several papers, but we did not obtain any CFU of this genus: this evidence could be explained as an effect of the methodology used to obtain the fungi colonies as suggested by BATEMAN et al. (2016). Moreover, only dispersing individuals have fully developed mycangia containing spores of the main fungal mutualists (LI et al., 2019) and it could be possible that beetles collected from the galleries could not have reached the dispersal life stage. Moreover, Ambrosiella fungi are contained, and unexposed, mainly in the mycangi or tunnels, and their presence on the body surface of $X$. compactus could be limited. A similar explanation could be for the lack of Fusarium, previously found by INTACHAT and KIRTON (1997), on the surface of $X$. compactus. Indeed, in our experiment, the beetles were allowed to release spores on plate with a free walk, while Bateman and co-authors (2016) isolated fungi from the washing solution of the surface of insects. Although the choice of primers for the amplification of ITS locus could introduce a bias in the identification of some fungal genera, in this work we successfully amplified and sequenced this target sequence from all the colonies analysed.

The present study describes the fungi associated with the body surface of $X$. compactus and L. colchicum when these species coexist in laurel twigs collected in one common natural environment. Both scolytids seem to be able to carry potential phytopathogenic fungi, such as Geosmithia spp. and Cladosporium spp.; the presence of such species on $X$. compactus adults was significantly higher than in L. colchicum. Cladosporium is an extremely common fungal genus that can be isolated from a huge variety of substrates (from soil to plants, air, etc.) and its great abundance is not unexpected. Generally, it includes saprophytic species even if phytopathogenic, mycopathogenic and some weakly human parasitic species are also included (BENSCH et al., 2012; 2015). Several species of Cladosporium have already been reported associated with $X$. compactus in 


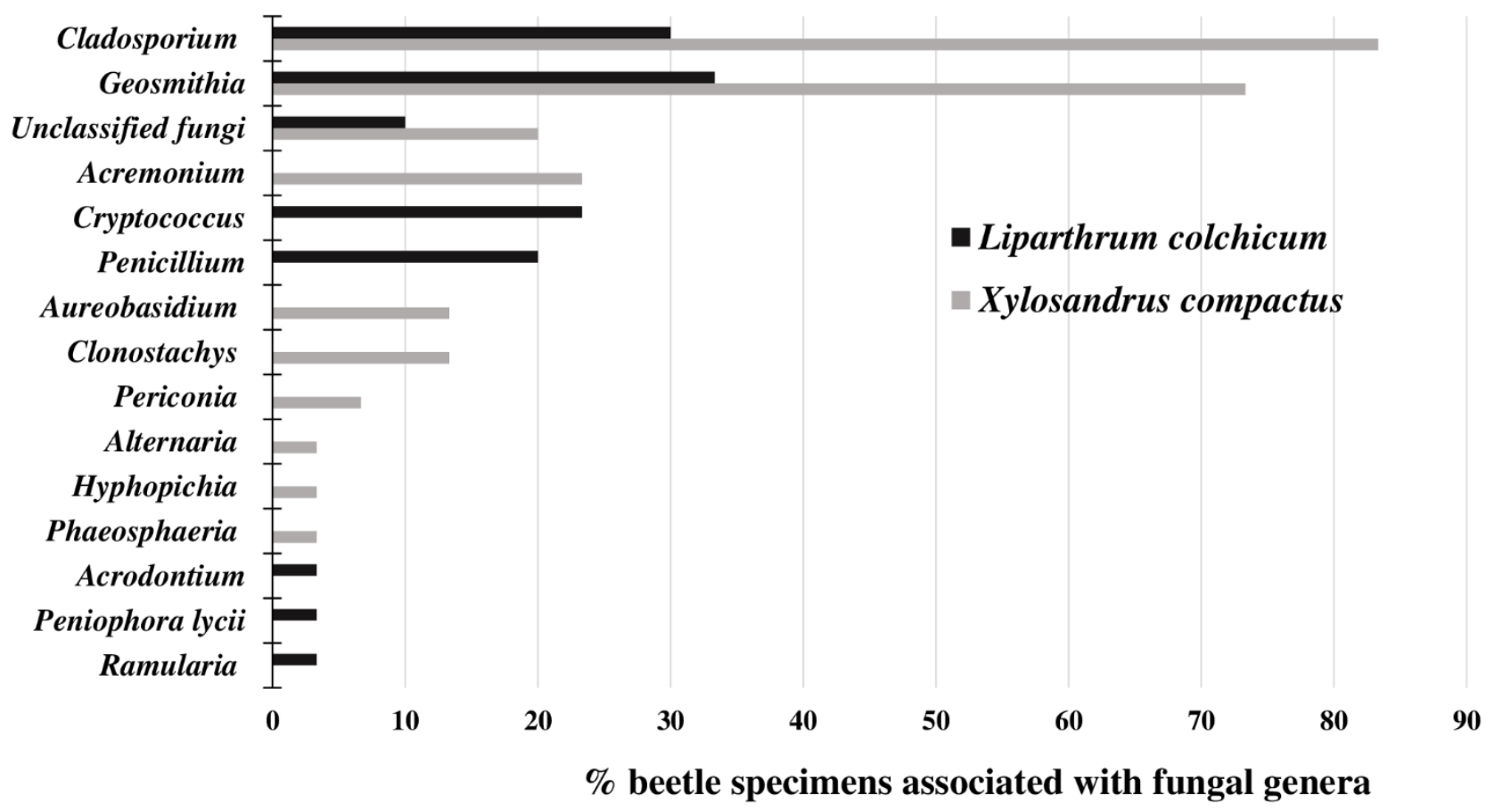

Fig. I - Percentage of X. compactus and L. colchicum specimens associated with the identified fungal genera. Scolytinae specimens were rated as associated with fungi when at least one CFUs could be detected on Petri plates.

Table 1 - Biodiversity indexes and Monte Carlo permutation test's probability (P).

\begin{tabular}{|l|c|c|c|}
\hline \multicolumn{2}{|c|}{ Biodiversity indexes, significance (Permutation test) } \\
\hline Taxa S & on Lyparthrum & on Xylosandrus & P \\
\hline Individuals & 9 & 11 & 0.8486 \\
\hline Dominance & 0.3105 & 204 & 0.3613 \\
\hline Shannon H & 1.487 & 0.2732 & 0.4113 \\
\hline Evenness e^H/S & 0.4914 & 0.4673 & 0.8808 \\
\hline Simpson indx & 0.6895 & 0.7268 & 0.3613 \\
\hline Menhinick & 1.026 & 0.7702 & 0.4547 \\
\hline Margalef & 1.842 & 1.88 & 1 \\
\hline Equitability J & 0.6766 & 0.6827 & 0.9319 \\
\hline Fisher alpha & 2.643 & 2.49 & 0.8586 \\
\hline Berger-Parker & 0.4935 & 0.3676 & 0.0404 \\
\hline
\end{tabular}


Italy and with other bark beetles (JANKOWIAK et al., 2007; BATEMAN et al., 2016; MORALES-RODRÍGUEZ et al., 2020). However, this is the first time that the fungus was found associated with L. colchicum.

Geosmithia species are, instead, cosmopolitan but understudied fungi; most of them are associated with phloem-feeding bark beetles on various woody hosts (ČÍŽKOVÁ et al., 2005; JANKOWIAK et al., 2014; HÄNZI et al., 2016; PEPORI et al., 2015). This genus has been previously associated on the body of $L$. colchicum as previously described in KOLAŘíK et al. (2004, 2007). The presence of Geosmithia spp. with X. compactus has been reported for the first time only recently (VANNINI et al., 2017; GUGLIUZZO et al., 2020; MORALES-RODRÍGUEZ et al., 2020). Three fungal genera were found associated only with X. compactus: Clonostachys, Aureobasidium and Acremonium.

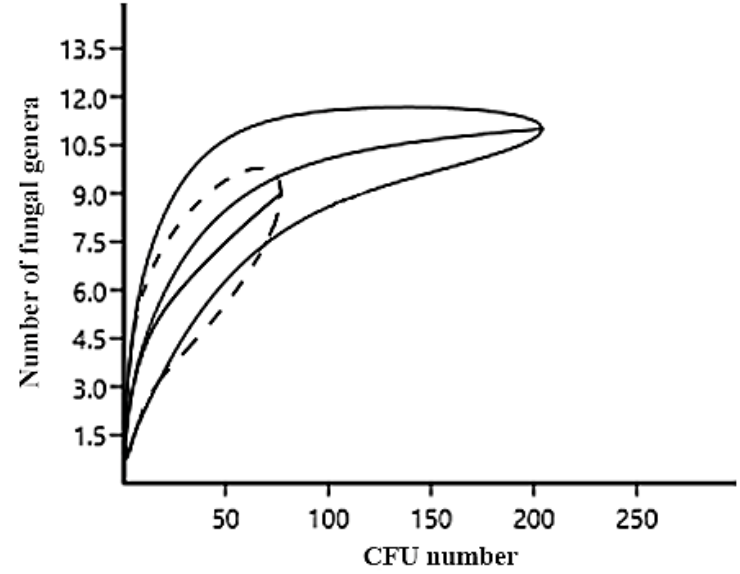

Fig. II - Individual rarefaction curves of $X$. compactus (continuous line) and L. colchicum (dashed line).

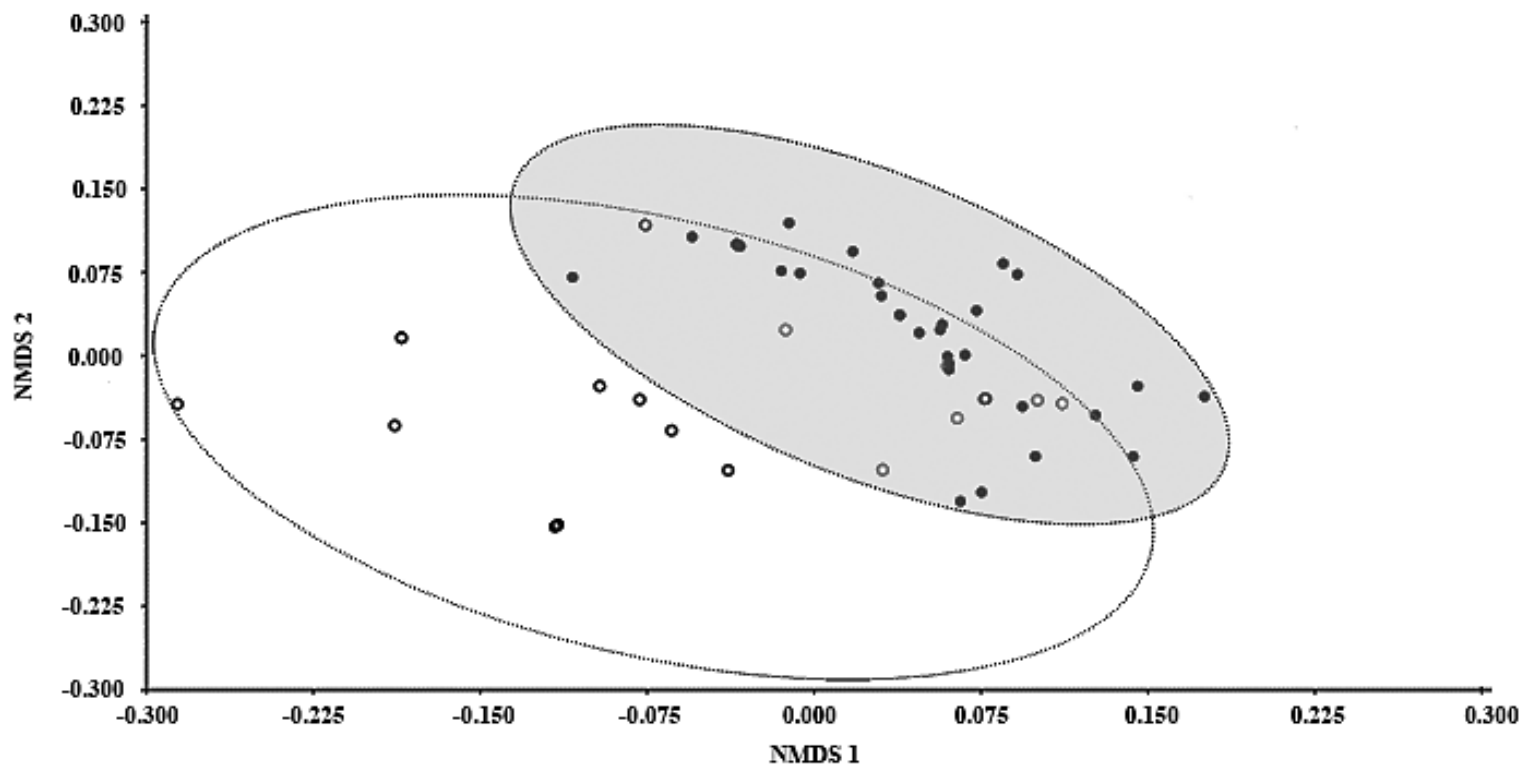

Fig. III - Non-metric multidimensional scaling (NMDS) analysis of the fungal communities carried by X. compactus (black dots) and L. colchicum (empty dots).

Filamentous fungi belonging to the genus Clonostachys are worldwide spread and colonize several habitats, particularly soil. Species of this genera are known as excellent parasite of numerous fungal plant pathogens, nematodes and insects. According to MORALESRODRÍGUEZ et al. (2020), Clonostachys is reported on $L$. nobilis and $Q$. ilex associated with $X$. compactus.

Aureobasidium is a ubiquitous and generalist black, yeast-like fungus that can be found in different environments. This genus was reported as associated with ambrosia beetle such as $X$. saxesenii (MALACRINO et al., 2017; RASSATI et al., 2019).

Furthermore, the Acremonium genus includes more than 100 species, mostly saprophytic but also pathogenic for plants, insects and other fungi. This genus was found associated to X. compactus by MuŁENKO et al. (2008) and PERDOMO et al. (2011) on Laurus nobilis. Hyphopichia is a ubiquitous and generalistic yeast-like fungus that can be found in different environments. Alternaria is an ubiquitary fungal genus that is frequently found in Italy on rotting fruit and vegetables as well as on plants, in which it plays a role as a phytopathogen. Phaeosphaeria is a major fungal pathogen affecting all major crop plant families and its association with $X$. compactus has been reported for the first time only recently (VANNINI et al., 2017, GUGLIUZZO et al., 2020, MORALES-RODRIGUEZ et al., 2020), while Acremonium sp., Alternaria sp., Aureobasidium sp., Cladosporium sp. and Clonostachys sp. are genera well known to be associated to $X$. compactus. At the same time, two genera were found associated only with $L$. colchicum but not with $X$. compactus: Penicillium and Cryptococcus. 
The genus Penicillium is ubiquitous, epiphytic in different crops and endophytic in the inner tissues of living plants. Species of the genus Penicillium play a key role in post-harvest conservation and spoilage of vegetal material (LOUW and KORSTEN, 2014).

The yeast genus Cryptococcus is a well-known mammalian pathogen but generally not of phytopathogenic interest, however some species, such as C. laurentii, could be used in biocontrol strategies (QIN and TIAN, 2005).

Considering the data obtained in this study and those reported in literature, $X$. compactus could be considered a vector for Clonostachys, Aureobasidium and Acremonium, while, so far, L. colchicum did not seem to be associated to these genera. On the other hand, $L$. colchicum could contribute to diffusion of Cryptococcus but it could not be considered an exclusive factor for the diffusion of Penicillium because this genus was previously found associated also with $X$. compactus on $L$. nobilis by several authors (PETERSON et al.,2003; PETERSON et al., 2005; PETERSON et al., 2015 and CAO et al., 2019). In addition, Penicillium spores are primarily wind-dispersed and could not strictly depend on beetle vectors for dissemination (GRINN-GOFROŃ, 2011). According to the emerged evidences, by considering overall the biodiversity indexes measured, not remarkable differences were highlighted between the composition of fungal communities carried by $X$. compactus and by L. colchicum. Only the Berger-Parker dominance index resulted to be statistically significant due to the higher frequency in $X$. compactus of the most common fungal genera detected.

A fundamental difference between the two beetles consists in the polyphagous behaviour of $X$. compactus, able to colonize different hosts, while the laurel is the specific host of $L$ colchicum. For this reason, the possible spread of $X$. compactus and its associated fungi can represent an added major risk for woody plants, cultivated for fruit production, ornamental and forestry purposes in EPPO region.

\section{ACKNOWLEDGEMENT}

We sincerely thank the Dukes Salviati for their support during the samplings in "Tenuta Salviati". Moreover, we are particularly obligated to Mrs Silvia Cinacchi, chief administrative officer of Villa Salviati park for supervising field logistics and Mr. Paolo Marradini for joining us during the investigations in the same park. We also thank Mr. Riccardo Frosinini and Mrs Franca Tarchi for laboratory support.

The study was performed within the project "Contributi per il controllo delle emergenze fitosanitarie determinate da Xylosandrus compactus, Xylella fastidiosa, Bortytis cinerea" (Control of parasites and pathogens related to phytosanitary emergencies: Xylosandrus compactus, Xylella fastidiosa, Bortytis cinerea) (CO.XI.BO)" (D.M. 0037134 of $31 / 12 / 2018$ ) funded by the Ministry of Agricultural, Food and Forestry Policies-MiPAAF.

\section{REFERENCES}

BAteman C., Šigut M., Skelton J., SMith K.E., HulcR J., 2016 - Fungal associates of the Xylosandrus compactus (Coleoptera: Curculionidae, Scolytinae) are spatially segregated on the insect body. Environmental Entomology, 45: 883-890. doi: 10.1093/ee/nvw070

BeAver R., Wilding N., Collins N., HAMmond P., WEBBER J., 1989 - Insect-fungus relationships in the bark and ambrosia beetles. - Insect-fungus interactions, 121: 143. doi: 10.1016/B978-0-12751800-8.50011-2

Bensch K., Braun U., Groenewald J.Z., Crous P.W., 2012 - The genus Cladosporium. - Stud. Mycol., 72: 1-401. doi: 10.3114/sim0003

BENSCH K., GROENEWALD J.Z., BRAUN U., DiJKsTERhUIS J., DE JEsÚS YÁÑEZ-MORALES M., Crous P.W., 2015 - Common but different: The expanding realm of Cladosporium. - Stud. Mycol., 82 23-74. doi: 10.1016/j.simyco.2015.10.001

BROWN D., P. ROTHERY., 1993 - Models in biology: mathematics, statistics and computing. John Wiley and Sons; Chichester, New York, Brisbane, Toronto, Singapore 1993, 688 pp doi:10.1002/bimj.47103 60615

CAO J., Li X.-M., Li X., Li H.-L., MenG L.-H., WANG B.G., 2019 - New lactone and isocoumarin derivatives from the marine mangrove-derived endophytic fungus Penicillium coffeae MA-314. Phytochemistry Letters, 32: 1-5. doi: j.phytol.2019. 04.018

ChaO A., Gotelli N.J., Hsieh T.C., SANDER E.L., MA K.H., COLWEll R.K., EllisON A.M., 2014 Rarefaction and extrapolation with Hill numbers: a framework for sampling and estimation in species diversity studies. - Ecological Monographs, 84: 4567.

ČÍŽKOVÁ D., ŠRŮTKA P., KolǍ̌íK M., KuBÁTOVÁ A., PAŽOUTOVÁ S., 2005 - Assessing the pathogenic effect of Fusarium, Geosmithia and Ophiostoma fungi from broad-leaved trees. - Folia Microbiologica, 50: 59-62. doi: 10.1007/BF02931294

DAEHLER C.C., DUDLEY N., 2002 - Impact of the black twig borer, an introduced insect pest, on Acacia koa in the Hawaiian Islands. - Micronesica, 6: 35-53.

DIXON W.N., WOODRUFF R.E., 1983 - The black twig borer, Xylosandrus compactus (Eichhoff) (Coleoptera: Scolytidae), pp. 2 Florida Department of Agriculture and Consumer Services, Gainesville, USA.

FACCOLI M., 2021 - Xylosandrus compactus, un nuovo parassita forestale invade l'Italia. - Forest@ - Rivista di Selvicoltura ed Ecologia Forestale, 18: 8-14. doi: 10.3832/efor3711-018

FITOLAB, 2011a - Monitore fitosanitario. www.agricoltura.regione.campania.it/difesa/monitor e_2011.html

FITOLAB, 2011b - Xylosandrus compactus. www.agricoltura.regione.campania.it/difesa/xylosan drus_2011.html 
Francardi V., Noal A., Francescato S., Pinto R., BRUNi A., LOFFredi L., BUCINI D., GUARNIERI D., BEllANTUONO M., EsPosito N., 2017 - Coexistence of Xylosandrus crassiusculus (Motschulsky) and X. compactus (Eichhoff)(Coleoptera Curculionidae Scolytinae) in the National Park of Circeo (Lazio, Italy). - Redia, 100: 149-155. doi: 10.19263/REDIA100.17.19

Francardi V., Pennacchio F., Santini L., Rumine P., PaOli A., Navarra A., Musetti N., 2012 - Prima segnalazione di Xylosandrus compactus su Laurus nobilis in Toscana. - Giornate Fitopatologiche, 13: 443-446.

FranCARdi V., VitAle S., Strangi A., BinAZZI F., BENVENUTI C., BARZANTI G.P., LUONGO L., LANDI S., PENNACCHIO F., 2021 - Liparthrum colchicum Semenov (Coleoptera Curculionidae Scolytinae) in Italy: introduced, established or native species? Redia, 104: 55-61.

http://dx.doi.org/10.19263/REDIA-104.21.06

Garonna A.P., Dole S.A., SARAcino A., MAZZOLENI S., CRISTINZIO G., 2012 - First record of the black twig borer Xylosandrus compactus (Eichhoff)(Coleoptera: Curculionidae, Scolytinae) from Europe. - Zootaxa, 3251: 64-68.

GrINN-GoFroń A., 2011 - Airborne Aspergillus and Penicillium in the atmosphere of Szczecin, (Poland) (2004-2009). - Aerobiologia, 27: 67-76. doi: 10.1007/s10453-010-9177-8

Gugliuzzo A., Criscione G., Biondi A., Aiello D., Vitale A., Polizzi G., Tropea Garzia G., 2020 Seasonal changes in population structure of the ambrosia beetle Xylosandrus compactus and its associated fungi in a southern Mediterranean environment. - PLoS One, 15: e0239011. doi: 10.1371/journal.pone.0239011

Gugliuzzo A., Criscione G., Siscaro G., Russo A., TropeA GARZIA G., 2019a - First data on the flight activity and distribution of the ambrosia beetle Xylosandrus compactus (Eichhoff) on carob trees in Sicily. - EPPO Bulletin, 49: 340-351. doi: 10.1111/epp. 12564

Gugliuzzo A., Criscione G., Tropea Garzia G., 2019 b - Unusual behavior of Xylosandrus compactus (Coleoptera: Scolytinae) on Carob trees in a Mediterranean environment. - Insects, 10: 82. doi: 10.3390/insects10030082

Gugliuzzo A., Mazzeo G., MAnsour R., Garzia G.T., $2019 \mathrm{c}-$ Carob pests in the Mediterranean region: bio-ecology, natural enemies and management options. - Phytoparasitica, 47: 605-628. doi: 10.1007/s12600-019-00766-7

HAMMER Ø., HARPER D.A.T., RYAN P.D. 2001 - PAST: Paleontological statistics software package for education and data analysis. - Palaeontologia Electronica, 4(1): 9. $\quad \mathrm{http}: / /$ palaeoelectronica.org/2001_1/past/issue1_01.htm

HÄNZI M., COCHARD B., Chablais R., CROVAdORE J., LEFORT F., 2016 - First report of Geosmithia langdonii and Geosmithia spp. isolated from a decaying elm (Ulmus minor) in Geneva, Switzerland.
- Folia Forestalia Polonica, 58: 96-102. doi: 10.1515/ffp-2016-0011

INTACHAT J., KIRTON L., 1997 - Observations on insects associated with Acacia mangium in Peninsular Malaysia. - Journal of Tropical Forest Science, 9: 561-564.

JANKOWIAK R., KOLAŘíK M., BILAŃSKI P., 2014 Association of Geosmithia fungi (Ascomycota: Hypocreales) with pine-and spruce-infesting bark beetles in Poland. - Fungal Ecology, 11: 71-79. doi: 10.1016/j.funeco.2014.04.002

JANKOWIAK R., Rossa R., Mista K., 2007 - Survey of fungal species vectored by Ips cembrae to European larch trees in Raciborskie forests (Poland). - Czech Mycology, 59: 227.

JORDAL B.H., KIRKENDALL L.R., HARKESTAD K., 2004 Phylogeny of a Macaronesian radiation: host-plant use and possible cryptic speciation in Liparthrum bark beetles. - Molecular phylogenetics and evolution, 31: 554-571. doi: 10.1016/j.ympev.2003.09.008

KIRAN V., ASOKAN R., REVANNAVAR R., HANCHIPURA MALlESH M.S., RAMASAMY E., 2019 - Genetic characterization and DNA barcoding of coffee shothole borer, Xylosandrus compactus (Eichhoff) (Coleoptera: Curculionidae: Scolytinae). Mitochondrial DNA Part A, 30: 779-785. doi: 10.1080/24701394.2019.1659249

KolaŘíK M., KostovČíK M., PAŽOutovÁ S., 2007 Host range and diversity of the genus Geosmithia (Ascomycota: Hypocreales) living in association with bark beetles in the Mediterranean area. Mycological Research, 111: 1298-1310. doi: 10.1016/j.mycres.2007.06.010

KolAŘíK M., KuBÁTOVÁ A., PAŽOUTOVÁ S., 2004 Morphological and molecular characterisation of Geosmithia putterillii, G. pallida comb. nov. and G. flava sp. nov., associated with subcorticolous insects. - Mycological Research, 108: 1053-1069.

Li Y., RUAN Y.Y., StANLEY E.L., SKelton J., HulCR J., 2019 - Plasticity of mycangia in Xylosandrus ambrosia beetles. Insect Science 26: 732-742. doi: 10.1111/1744-7917.12590.

LOngo S., Tropea Garzia G., 2016 - Uno Scolitide asiatico nocivo al Carrubo in Sicilia, http://www.georgofili.info/contenuti/uno-scolitideasiatico-nocivo-al-carrubo-in-sicilia/2909 (Last accessed: December 2020)

LOUW J.P., KoRSTEN L., 2014 - Pathogenic Penicillium spp. on apple and pear. - Plant Disease, 98: 590-598. doi: 10.1094/PDIS-07-13-0710-RE

MAlacrino A., RASSATi D., SchENA L., MEHZABIN R., BATtisti A., PALMERI V., 2017 - Fungal communities associated with bark and ambrosia beetles trapped at international harbours. - Fungal Ecology, 28: 44-52. doi: 10.1016/j.funeco.2017.04.007

MAтsumoto K., 2002 - Insect pests of Mahogany in Indonesia and Malaysia. - Tropical Forestry, 55: 2936.

Meshram P.B., Husen M., Joshi K.C., 1993 - A new 
report of ambrosia beetle, Xylosandrus compactus Eichhoff.(Coleoptera: Scolytidae) as a pest of African mahogany, Khaya sp. - Indian Forester, 119: 75-77.

Morales-RodríGUEZ C., SFERRAZZA I., ALEANDRI M.P., Dalla Valle M., Speranza S., CONTARINI M., VANNINI A., 2020 - The fungal community associated with the ambrosia beetle Xylosandrus compactus invading the mediterranean maquis in central Italy reveals high biodiversity and suggests environmental acquisitions. - Fungal Biology, 125: 12-24. doi: 10.1016/j.funbio.2020.09.008

MuŁENKO W., MAJEWSKI T., RUSZKIEWICZ-MichaLSKA M., 2008 - A preliminary checklist of micromycetes in Poland. - W. Szafer Institute of Botany, Polish Academy of Sciences, Kraków: 752 pp.

NgOAN N., Wilkinson R., Short D., Moses C., MANGOLD J., 1976 - Biology of an introduced ambrosia beetle, Xylosandrus compactus, in Florida. - Annals of the Entomological Society of America, 69: 872-876. doi: 10.1093/aesa/69.5.872

Pennacchio F., SAnTini L., Francardi V., 2012 Bioecological notes on Xylosandrus compactus (Eichhoff) (Coleoptera Curculionidae Scolytinae), a species recently recorded into Italy. - Redia, 95: 6777.

PePORI A.L., KolaříK M., Bettini P.P., VetTraino A.M., SANTINI A., 2015 - Morphological and molecular characterisation of Geosmithia species on European elms. - Fungal Biology, 119(11):10631074. doi: 10.1016/j.funbio.2015.08.003.

Perdomo H., Sutton D., García D., Fothergill A., CANo J., Gené J., Summerbell R., Rinaldi M., GUARRO J., 2011 - Spectrum of clinically relevant Acremonium species in the United States. - Journal of Clinical Microbiology, 49: 243-256. doi: 10.1128/JCM.00793-10

Peterson S.W., JuRJEVIĆ Ž., Frisvad J.C., 2015 Expanding the Species and Chemical Diversity of Penicillium Section Cinnamopurpurea. - PLoS One, 10: e0121987. doi: 10.1371/journal.pone.0121987

Peterson S.W., PÉrez J., Vega F.E., Infante F., 2003 - Penicillium brocae, a new species associated with the coffee berry borer in Chiapas, Mexico. -
Mycologia, 95: 141-147. doi: 10.1080/15572536.2004.11833143

Peterson S.W., Vega F.E., Posada F., NAGai C., 2005 - Penicillium coffeae, a new endophytic species isolated from a coffee plant and its phylogenetic relationship to $\mathrm{P}$. fellutanum, $\mathrm{P}$. thiersii and $\mathrm{P}$. brocae based on parsimony analysis of multilocus DNA sequences. - Mycologia, 97: 659-666. doi: 10.1080/15572536.2006.11832796

PFEFFER A., 1995 - Bark and Ambrosia beetles from the central and west palaearctic region (Coleoptera, Scolytidae, Platypodidae). - Entomologica Basiliensia, 17: 5-310.

QIN G.Z., TIAN S.P., 2005 - Enhancement of biocontrol activity of Cryptococcus laurentii by silicon and the possible mechanisms involved. - Phytopathology, 95: 69-75. doi: 10.1094/phyto-95-0069

RASSATI D., MARINI L., MALACRINÒ A., 2019 Acquisition of fungi from the environment modifies ambrosia beetle mycobiome during invasion. - PeerJ, 7: e8103. doi: 10.7717/peerj.8103

VANNINI A., CONTARINI M., FACCOLI M., VALle M.D., Rodriguez C., MAZzetTo T., GUARneri D., VETTRAINO A., SPERANZA S., 2017 - First report of the ambrosia beetle Xylosandrus compactus and associated fungi in the Mediterranean maquis in Italy, and new host-pest associations. - EPPO Bulletin, 47: 100-103. doi: 10.1111/epp.12358

WhITE T.J., BRUNS T., LEE S.J.W.T., TAYLOR J.W., 1990 - Amplification and direct sequencing of fungal ribosomal RNA genes for phylogenetics. - PCR protocols: a guide to methods and applications, 18: 315-322.

WoOD S.L., 1982 - The bark and ambrosia beetles of North and Central America (Coleoptera: Scolytidae), a taxonomic monograph.- $1359 \mathrm{pp}$.

WoOD S.L., 2007 - Bark and ambrosia beetles of south America (Coleoptera, Scolytidae).- Monte L. Bean Science Museum, Provo, Utah: 900 pp.

WoOD S.L., BRIGHT D.E.J., 1992 - A catalog of Scolytidae and Platypodidae (Coleoptera), Part 2: taxonomic index. $1553 \mathrm{pp}$. 